\title{
Potential of Predator Podisus nigrispinus Dallas (Hemiptera: Pentatomidae) in the Control of Helicoverpa armigera Hübner (Lepidoptera: Noctuidae)
}

\author{
Juliana Simonato $^{1}$, Harley N. de Oliveira ${ }^{2}$, José F. J. Grigolli ${ }^{3}$, Mirian M. Kubota Grigolli ${ }^{3} \&$ Ivana F. da Silva $^{1}$ \\ ${ }^{1}$ Programa de Pós-Graduação em Entomologia e Conservação da Biodiversidade, Universidade Federal da \\ Grande Dourados, Dourados, MS, Brazil \\ ${ }^{2}$ Embrapa Agropecuária Oeste, Dourados, MS, Brazil \\ ${ }^{3}$ Fundação MS para Pesquisa e Difusão de Tecnologias Agropecuárias, Maracaju, MS, Brazil \\ Correspondence: Ivana F. da Silva, Programa de Pós-Graduação em Entomologia e Conservação da \\ Biodiversidade, Universidade Federal da Grande Dourados, Dourados, MS, Brazil. E-mail: \\ ivanaf.silva@hotmail.com
}

Received: November 27, 2019

Accepted: January 2, $2020 \quad$ Online Published: February 15, 2020

doi:10.5539/jas.v12n3p204

URL: https://doi.org/10.5539/jas.v12n3p204

\begin{abstract}
Managing Helicoverpa armigera is still a major challenge for Brazilian farmers, due to limited information available about chemicals and biological control of this pest in Brazil. This study focused on evaluating the biological aspects of Podisus nigrispinus fed with $H$. armigera, under laboratory conditions, as well as verifying the capacity of the P. nigrispinus in preying on caterpillars of $H$. armigera in the field, in soybean crops. The experiments were conducted in laboratory under controlled temperature conditions of $25 \pm 2{ }^{\circ} \mathrm{C}$, relative humidity (RH) $60 \pm 10 \%$ and 14-hour photophase, as well as in the field, at the experimental station of Fundação MS in Maracaju, MS. In the laboratory, second instar nymphs of P. nigrispinus were placed in plastic jars and fed with H. armigera larvae or Tenebrio molitor larvae throughout the nymphal phase. When they reach adulthood, 15 couples were formed, remaining with the same prey of the previous phase. For the field trial, soybean plants were caged, and inside these cages were released eight quarter-instar $H$. armigera caterpillars. Subsequently, in each cage were released an adult female or a fifth instar nymph, and after 24 hours, the number of prey caterpillars were assessed. Predator nymphal duration was shorter in treatment with $H$. armigera than with $T$. molitor. Nymphal viability was similar between treatments. Adult females and males fed with $H$. armigera presented greater body mass than those fed with $T$. molitor. The number of postures per female and the number of eggs per female were similar between treatments. The incubation period of eggs was longer for treatment with $H$. armigera, differing statistically from treatment with $T$. molitor. Eggs from treatment with $H$. armigera showed similar viability to treatment with $T$. molitor, not differing statistically. Females and males under treatment with $H$. armigera showed longer longevity compared to treatment with $T$. molitor. Adult females preyed on average 2.26 caterpillars within 24 hours and fifth instar nymphs preyed on 1.73 caterpillars/day. $P$. nigrispinus showed better development when fed with $H$. armigera, demonstrating that it can be used as an alternative host for breeding this predator. The predator showed satisfactory performance for predation rate/day. Release of fifth instar nymphs and adult females of P. nigrispinus may reduce the pest population in relation to the absence of the predator under field conditions, an important alternative to be used in H. armigera integrated management programs.
\end{abstract}

Keywords: predatory stink bug, asopinae, biological control, old-world caterpillar

\section{Introduction}

Brazil is one of the world's largest producers of soybeans, reaching record production of 114.843 million tons in the 2018/2019 crop and according to forecasts, soybean production will have a significant increase in the 2019/2020 crop, constituting a new production record (CONAB, 2019). However, this increase in production could be threatened due to phytosanitary problems that Brazilian producers have been facing, including the possibility of recurrence of Helicoverpa armigera caterpillars (Hübner, 1805) (Lepidoptera: Noctuidae) in the production fields (Dias et al., 2019). 
Helicoverpa armigera has a worldwide distribution, occurring in countries in Asia, Africa, Europe and Oceania (Guo, 1997), and was first recorded in Brazil, officially, in the 2012/2013 harvest (Ávila et al., 2013; Czepak et al., 2013). It is a highly polyphagous species, and its caterpillars are found in more than 60 species of wild and cultivated plants, feeding on leaves and stems, however, they prefer shoots, inflorescences, fruits and pods, causing damage to both the vegetative phase and the reproductive phase of plants, impairing several crops (Oliveira et al., 2016). Managing $H$. armigera populations is still a major challenge for Brazilian farmers, given limited information available on chemicals and biological control of this pest in Brazil (Grigolli et al., 2016; Dias et al., 2019). However, due to awareness on the need to maintain environmental quality and human health safety, insect pest suppression methods have been a source of concern for society. In this context, it is necessary to seek an agricultural production system that contemplates environmental sustainability and promotes biodiversity in the agroecosystem (Oliveira \& Ávila, 2010). Biological control using tactics to conserve or increase natural enemies in agroecosystems is a reality that needs to be investigated and explored under Brazilian conditions (Ávila et al., 2013), being an important tool for the control of H. armigera (Fathipour \& Sedaratian, 2013). Among the predatory insects found naturally in agroecosystems, species of the Podisus genus present general feeding habits, being registered in several cultures feeding preferentially on lepidopteran caterpillars (Oliveira et al., 1999). The predatory stink bug Podisus nigrispinus (Dallas, 1851) (Hemiptera: Pentatomidae) is the subfamily species Asopinae most commonly found in Brazil and is found naturally in agricultural and forest ecosystems, preying on leafless caterpillars, as well as larvae and pupae of beetles and nymphs and adults of phytophagous stink bugs (Oliveira et al., 2008; Moura \& Grazia, 2011). However, it is necessary to understand the interactions between ecological, behavioral, physiological and nutritional factors, as basis for the successful use of insects in pest control (Thompson, 1999).

The development and reproduction of $P$. nigrispinus may vary with the prey used (Lacerda et al., 2004; Lemos et al., 2005; Mahdian et al., 2006), which may have implications for mass production as well as the effectiveness of biological pest control in the field for different crops (Oliveira et al., 2004a). According to Oliveira et al. (2004a), predation potential studies should prioritize the mass breeding of these insects under laboratory conditions, and subsequently released into the field for biological control of key pests in various crops. In this context, it is vital to study the prey species most suitable for the production of $P$. nigrispinus, allowing mass multiplication; thus, its use in integrated pest management programs (Botteon et al., 2016). Despite the importance of Podisus sp. biological control in soybean cultivation and the existence of several studies on techniques for its mass rearing in the laboratory (De Clercq et al., 1988; Saavedra et al., 1992, 1995; Zanuncio et al., 1992; Torres et al., 2006), there is little information on the applied use of this biological control agent in soybean crop in Brazil (Bueno et al., 2014). Therefore, this study focused on evaluating biological aspects of the development and reproduction of $H$. armigera predator P. nigrispinus in laboratory, as well as to verify the predation capacity of $H$. armigera caterpillars in soybean, under field conditions.

\section{Material and Methods}

The experiment was conducted at the Entomology Laboratory of Fundação MS $\left(22^{\circ} 08^{\prime} \mathrm{S} ; 52^{\circ} 44^{\prime} \mathrm{W}, 425 \mathrm{~m}\right.$ altitude), with the predator P. nigrispinus and prey H. armigera and Tenebrio molitor (Linnaeus, 1758) (Coleoptera: Tenebrionidae). Predator and prey rearing, as well as experiments, were maintained under controlled temperature of $25 \pm 2{ }^{\circ} \mathrm{C}$, relative humidity (RH) of $60 \pm 10 \%$ and 14-hour photophase. The field experiment was conducted in an experimental area of Fundação MS located in the municipality of Maracaju, MS The P. nigrispinus individuals used in the experiment were kept in PVC pipes and were fed with $T$. molitor larvae as described by Zanuncio et al. (2001). T. molitor rearing was maintained in $29 \times 23 \times 11 \mathrm{~cm}$ (height $\times$ width $\times$ depth) plastic trays and fed with whole wheat flour (97\%), beer yeast (3\%) and chayote (Sechium edule), to provide the necessary water (Zamperline et al., 1992). The H. armigera caterpillars used in the experiment were obtained from the laboratory-maintained rearing, where adults were kept in $20 \times 25 \mathrm{~cm}$ (diameter $\times$ height) PVC cylindrical cages, fed with $10 \%$ honey solution for posture increase. Eggs were removed daily and placed in plastic jars containing artificial white bean diet (modified from Greene et al., 1976).

\subsection{Bioassay 1: Biological Aspects of P. nigrispinus Nymphs With H. armigera Larvae and T. molitor larvae as Prey}

For the nymphal phase evaluation of $P$. nigrispinus, a completely randomized design was used, with two treatments (H. armigera larvae and T. molitor larvae) and 15 replications. Each repetition consisted of $1000 \mathrm{ml}$ transparent plastic containers, with distilled water dampened cotton inside, dimensions of $15 \times 10 \mathrm{~cm}$ (diameter $\times$ height) and capped with plastic lid. Five P. nigrispinus second instar nymphs were placed in each container, and they were fed with caterpillars of each treatment ad libitum, throughout the nymphal phase of the predator. 
Material asepsis, water exchange and assessments were performed every 24 hours. The biological parameters assessed during the nymphal phase were: duration of each stage, nymphal phase duration and nymphal viability.

\subsection{Bioassay 2: Biological Aspects of P. nigrispinus Adults With H. armigera and T. molitor Larvae as Prey}

After the emergence of the adults, who were reared throughout the nymphal phase with $H$. armigera or T. molitor, 15 couples were formed per treatment (H. armigera larvae or T. molitor larvae), they were placed in $1000 \mathrm{ml}$ transparent containers, with water dampened cotton inside, dimensions of $15 \times 10 \mathrm{~cm}$ (diameter $\times$ height) and capped with plastic lid. One couple was housed per cage. Caterpillars and larvae used to feed couples were placed ad libitum in each treatment. The biological parameters evaluated were mass (mg) of newly emerged males and females, sex ratio, number of postures, total eggs per female, egg viability, incubation period and longevity of males and females. The experimental design adopted in this stage was completely randomized, with two treatments (H. armigera larvae and T. molitor larvae) and 15 replications.

\subsection{Bioassay 3: Potential of P. nigrispinus Predation in H. armigera Caterpillars in Soybean Under Field Conditions}

In an area of approximately 15 hectares sown with soybean (Glycine max (L.) Merrill), cultivar "BMX Potência RR" in a no-tillage system, cages made of pvc pipes and fittings, with a size of $1.00 \times 1.00 \mathrm{~m}$ (width $\times$ height) each cage, coated with voile fabric were randomly arranged, each covering approximately 12 soybean plants, free from pests and predators, with their bases covered with soil, to prevent their infestation by unwanted insects, as well as to prevent the escape of insects released inside. During the experiment, the soybean plants were between the R5 and R6 phenological stages (Fehr \& Caviness, 1977). In the upper leaves of the plants, eight fourth-instar caterpillars of $H$. armigera were released in each cage 8 hours before the predators were released. Fifth-instar nymphs and adult females of P. nigrispinus, up to $24 \mathrm{~h}$, were individualized and kept without food for $24 \mathrm{~h}$. After this period a nymph or an adult predator was released from each cage. The evaluations were performed 24 hours after the predator release and the number of prey caterpillars recorded during this period. The experimental design was completely randomized, with 15 replications for both adults and predator fifth-instar nymphs, each cage constituting one repetition.

Gathered data were submitted to homogeneity and normality analysis, according to the conditions. Subsequently, the $\mathrm{t}$-Test at $5 \%$ significance was conducted.

\section{Results and Discussion}

\subsection{Biological Aspects of P. nigrispinus Nymphs With H. armigera Larvae and T. molitor Larvae as Prey}

Regarding the nymphal phase, the duration of the second instar was longer in H. armigera treatment than in $T$. molitor treatment. Third and fourth instars showed no significant difference between treatments. Treatment with T. molitor presented a longer duration of the fifth instar than $H$. armigera. The duration of the nymphal period was shorter with $H$. armigera than with $T$. molitor. The nymphal viability showed no significant differences between treatments, with approximately $73.33 \%$ for $H$. armigera and $72.00 \%$ for $T$. molitor (Table 1 ).

Table 1. Period (days) of immature stages and nymphal viability (\%) of Podisus nigrispinus fed Helicoverpa armigera and Tenebrio molitor in laboratory. T $25 \pm 2{ }^{\circ} \mathrm{C}$, RH $60 \pm 10 \%$ and 14-hour photophase

\begin{tabular}{lllll}
\hline & \multicolumn{2}{c}{ Preys } & \multirow{2}{*}{ t-test } & CV (\%) \\
\cline { 2 - 3 } & H. armigera & T. molitor & & \\
\hline $2^{\text {nd }}$ instar & $4.26 \pm 0.16 \mathrm{a}$ & $3.66 \pm 0.17 \mathrm{~b}$ & $6.24^{*}$ & 16.64 \\
$3^{\text {rd }}$ instar & $3.57 \pm 0.16 \mathrm{a}$ & $3.72 \pm 0.15 \mathrm{a}$ & $0.82^{\text {ns }}$ & 12.24 \\
$4^{\text {th }}$ instar & $3.81 \pm 0.23 \mathrm{a}$ & $4.28 \pm 0.14 \mathrm{a}$ & $2.52^{\text {ns }}$ & 19.85 \\
$5^{\text {th }}$ instar & $4.79 \pm 0.27 \mathrm{~b}$ & $7.33 \pm 0.49 \mathrm{a}$ & $23.42^{* *}$ & 23.67 \\
Per. nymph (days) & $18.60 \pm 0.41 \mathrm{a}$ & $20.85 \pm 0.66 \mathrm{~b}$ & $7.61^{*}$ & 11.34 \\
Viab. nymph (\%) $^{2}$ & $73.33 \pm 4.22 \mathrm{a}$ & $72.00 \pm 5.45 \mathrm{a}$ & $0.03^{\text {ns }}$ & 26.99 \\
\hline
\end{tabular}

Note. Means followed by the same lowercase letter on the line do not differ statistically from each other by the t-Test at $5 \%$ probability. ${ }^{\text {ns }}$ Not significant, $*$ significant at $5 \%$ probability, ${ }^{* *}$ significant at $1 \%$ probability. ${ }^{1}$ Per. nymph: Nymph period. ${ }^{2}$ Viab. Nymph: Nymph viability.

Food quantity and quality affect parameters such as survival, mass gain, stage duration, egg number and longevity (Zanuncio et al., 2002; Peluzio et al., 2018). Comparing the nymph period found in this study (Table 1), 
with the means obtained by Vacari et al. (2007) using caterpillars of Diatraea saccharalis (Fabricius) (Lepidoptera: Crambidae), by Espíndula et al. (2010) using caterpillars of Heliothis virescens (Fabricius) (Lepidoptera: Noctuidae) and by Santana et al. (2017), using caterpillars of Spodoptera frugiperda (JE Smith) (Lepidoptera: Noctuidae), despite the variations in the different stages, when considering the nymphal period as a whole, the phase is similar, being 18.60 days for H. armigera (Table 1), 18,20; 19.40; and 19.61 days for D. saccharalis, $H$. virescens and $S$. frugiperda, respectively. The similarity in the duration of the nymphal phase indicates the adaptation of this predator to the different prey and also shows that the prey used does not influence the duration of the nymphal phase (Oliveira et al., 2004b). A shorter nymphal period is important, as it results in higher predator production, promoting predator population growth and, consequently, a better performance in field caterpillar control (Matos Neto et al., 2002; Juscelino-Filho et al., 2003), as well as the population increase in less time, in laboratory creations.

Nymphal viability did not differ statistically between treatments (Table 1). In other studies, the predator reached $89.00 \%$ of nymphal viability when fed with $D$. saccharalis caterpillars (Vacari et al., 2007), 88.60\% with Spodoptera cosmioides (Walker, 1858) (Lepidoptera: Noctuidae) (Denez et al., 2014), 64.00\% with S. frugiperda (Oliveira et al., 2004b) and 60.00\% com Thyrinteina arnobia (Stoll, 1782) (Lepidoptera: Geometridae) (Oliveira et al., 2011). The results obtained in this work demonstrate the adaptation of the predator P. nigrispinus to the prey $H$. armigera. Insects, especially early instars, may require a period of time to adapt to the new diet, which may interfere with their development and survival (Santana et al., 2017). For the biological aspects evaluated, $H$. armigera proved to be suitable prey for the immature phase of $P$. nigrispinus with results similar to those obtained with the alternative host $T$. molitor, usually employed in mass breeding of this predator.

\subsection{Biological Aspects of P. nigrispinus Adults With H. armigera Larvae and T. molitor Larvae as Prey}

$H$. armigera fed adults had a sex ratio of 0.47 with no significant difference compared to T. molitor prey ( 0.54$)$ (Table 2). H. armigera fed females and males had higher body mass than T. molitor fed females (Table 2). The result was similar to that reported by Oliveira et al. (2011) using T. arnobia caterpillars as food, being $65.39 \mathrm{mg}$ for females and $45.61 \mathrm{mg}$ for males; and when $S$. frugiperda caterpillars were used, the mass of females was $56.18 \mathrm{mg}$ and $40.81 \mathrm{mg}$ for males (Oliveira et al., 2004b), presenting lower results to those found in this study.

Table 2. Sex ratio, female and male mass (mg), number of postures and number of eggs of Podisus nigrispinus adults fed Helicoverpa armigera and Tenebrio molitor in laboratory. T $25 \pm 2{ }^{\circ} \mathrm{C}$, $\mathrm{RH} 60 \pm 10 \%$ and 14 -hour photophase

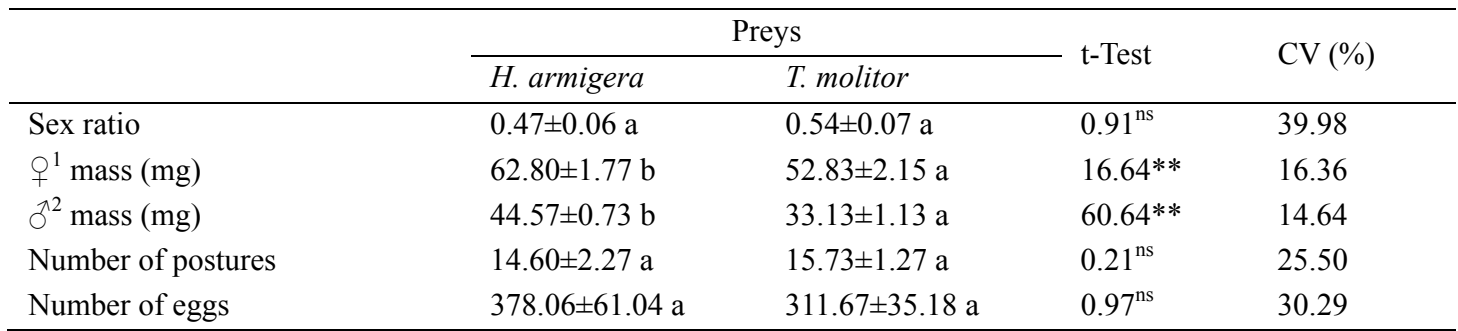

Note. Means followed by the same lowercase letter on the line do not differ statistically from each other by the t-test at $5 \%$ probability. ${ }^{\text {ns }}$ Not significant, $*$ significant at $5 \%$ probability, ${ }^{* *}$ significant at $1 \%$ probability.

${ }^{1}$ + : Females; ${ }^{2}{ }^{\gamma}$ : Males.

The greater mass of females is due to the accumulation of biomass necessary for the beginning of reproduction, since this parameter has been related to the development of their ovaries, as well as egg formation (Oliveira et al., 1999, 2011). The predator's mass reflects its diet, that is, properly fed individuals gain more mass than those who eat less (O’Neil \& Wiedenmann, 1990; Angelini \& Boiça Junior, 2015; De Bortoli et al., 2016). Thus, it can be inferred that $H$. armigera confers adequate performance to the predator P. nigrispinus by providing greater body mass when compared to T. molitor. The number of postures per female in the T. molitor treatment did not differ from the $H$. armigera treatment (Table 2). Similar result was found when fed with $S$. frugiperda (Oliveira et al., 2004b) and with T. molitor larvae in another study (Oliveira et al., 2004b; Espindula et al., 2010). When the prey used was $H$. virescens the number of postures was 8.89 (Espindula et al., 2010) and when the predator was fed with $D$. saccharalis it was on average 5.63 postures per female (Vacari et al., 2007). Although there was no statistical difference regarding the number of postures and number of eggs between the treatments, $P$. 
nigrispinus that fed on T. molitor presented numerically more postures, however, individuals from H. armigera treatment produced more eggs, demonstrating that the nutritional quality of this prey meets the predator's needs.

Fertility was similar between treatments (Table 2). The number of eggs per female of the H. armigera fed predator was similar to that found when fed with $S$. frugiperda, with a total of 447.62 eggs (Oliveira et al., 2004b); with Alabama argillacea (Hübner) (Lepidoptera: Noctuidae) it was 348.10 eggs (Oliveira et al., 2002); with T. molitor (392.76; 325.00) (Espindula et al., 2010; Oliveira et al., 2004b); 314.90 with T. arnobia (Oliveira et al., 2011) and larger than when fed with D. saccharalis (97.12) (Vacari et al., 2007). The higher number of eggs produced with the prey $S$. frugiperda, H. armigera, A. argillacea and T. molitor demonstrate that these species are nutritionally suitable for $P$. nigrispinus.

Regarding the egg incubation period, which was 6.04 days for $H$. armigera treatment, it was statistically different from T. molitor treatment, which was 6.62 days (Table 3). However, these values observed for both preys were lower than those reported by De Bortoli et al. (2016) when they used S. frugiperda (5.46 days) as prey Musca domestica (Linnaeus, 1758) (Diptera: Muscidae) (5.19 days) and A. gemmatalis (5.07 days).

Table 3. Incubation period (days), number of nymphs, nymphal viability (\%), male and female longevity (days) of adult Podisus nigrispinus adults fed Helicoverpa armigera and Tenebrio molitor in laboratory. T $25 \pm 2{ }^{\circ} \mathrm{C}, \mathrm{RH}$ $60 \pm 10 \%$ and 14-hour photophase

\begin{tabular}{lllll}
\hline & \multicolumn{2}{c}{ Preys } & \multirow{2}{*}{ t-Test } & CV $(\%)$ \\
\cline { 2 - 3 } & H. armigera & T. molitor & $6.75^{* *}$ & 6.74 \\
\hline Per. incubation (days) & $6.04 \pm 0.32 \mathrm{~b}$ & $6.62 \pm 0.48 \mathrm{a}$ & $1.10^{\mathrm{ns}}$ & 52.91 \\
Number of nymphs $_{\text {Nymph viability (\%) }}$ & $356.60 \pm 54.64 \mathrm{a}$ & $291.00 \pm 34.19 \mathrm{a}$ & $1.83^{\mathrm{ns}}$ & 7.86 \\
Longev. $^{2}{ }^{73}$ (days) & $96.13 \pm 1.32 \mathrm{a}$ & $92.46 \pm 2.06 \mathrm{a}$ & $0.16^{\mathrm{ns}}$ & 70.88 \\
Longev. $^{2}{ }^{4}$ (days) & $32.80 \pm 4.73 \mathrm{a}$ & $29.60 \pm 7.29 \mathrm{a}$ & $0.09^{\mathrm{ns}}$ & 53.52 \\
\hline
\end{tabular}

Note. Means followed by the same lowercase letter on the line do not differ statistically from each other by the t-test at $5 \%$ probability. ${ }^{\text {ns }}$ Not significant, $*$ significant at $5 \%$ probability, ${ }^{* *}$ significant at $1 \%$ probability.

${ }^{1}$ Per. incubation: Incubation period; ${ }^{2}$ Longev.: Longevity; ${ }^{3}{ }^{\lambda}$ : Males; ${ }^{4} \bigcirc$ : Females.

The number of nymphs depends on egg quality and viability. Eggs from $H$. armigera treatment presented viability similar to those from T. molitor treatment, not statistically different (Table 3). Espindula et al. (2010) by feeding $P$. nigrispinus with $H$. virescens, obtained viability of $65.09 \%$; with $D$. saccharalis the viability was $76.50 \%$ (Vacari et al., 2007), and the result was numerically similar to that reported by Oliveira et al. (2004) with the prey $S$. frugiperda (85.19\%). The higher egg viability suggests that $H$. armigera has the necessary nutritional requirements for a good predator development. The longevity of $P$. nigrispinus males and females fed $H$. armigera was similar to that observed in T. molitor treatment (Table 3). Overall, females were found to be approximately $13 \%$ lighter than males. This shorter longevity of females compared to males was also observed by Oliveira et al. (2011) when the prey used was T. arnobia, being 35.54 days for females and 43.08 days for males (Oliveira et al., 2011). In a study conducted by Espindula et al. (2010) the prey H. virescens found shorter longevity of females (40 days) compared to males (49.21 days). This fact can be explained by the high energy use of females for egg formation and oviposition (Oliveira et al., 2011). This is due to the allocation of energy during physiological processes, increasing the energy demand for egg production, leaving less energy for other processes such as longevity, for example (Sibly \& Calow, 1986).

Prey that is nutritionally adequate provides reduced development time, maximum survival rate and maximum reproductive rate, resulting in an increase in population. The development of this predator and its mortality rate may vary depending on the conversion efficiency of the food, so some predators are better suited to certain prey types that may provide faster development and longer survival (Stamp et al., 1991), as was verified when the predator was raised with $H$. armigera caterpillars.

\subsection{Predatory Potential of P. nigrispinus in H. armigera Caterpillars in Soybean Under Field Conditions}

After the predation period had elapsed, the cages were removed, the predators located and the collection of the remaining live and preyed caterpillars started, totaling the eight initially released caterpillars per cage (Figure 1). 

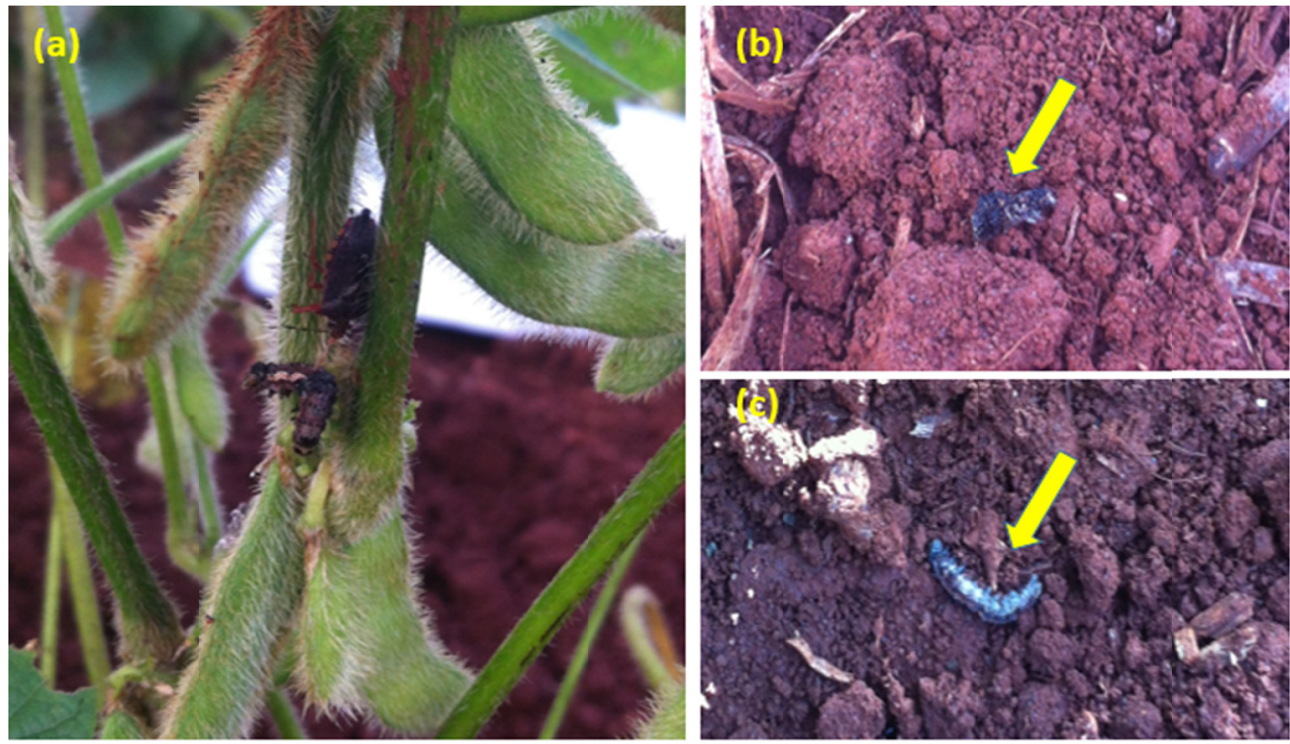

Figure 1. (a) Adult female of Podisus nigrispinus preying on Helicoverpa armigera caterpillar and (b, c) $H$. armigera caterpillars predated by P. nigrispinus in field on soybean crop. Photos: Juliana Simonato

Adult females preyed on average 2.26 caterpillars within 24 hours and fifth-instar nymphs preyed on 1.73 caterpillars/day, presenting statistical difference (Figure 2).

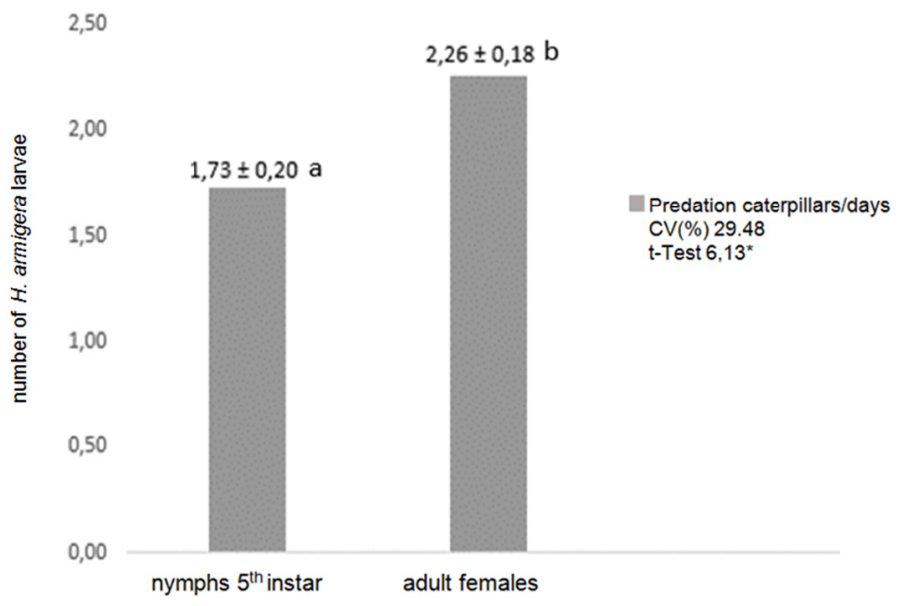

Figure 2. Averages ( $\pm \mathrm{SE}$ ) of the number of Helicoverpa armigera larvae predated by Podisus nigrispinus in 24 hours in soybean under field conditions. Means followed by the same letter do not differ statistically from each other by the t-Test at $5 \%$ probability. ${ }^{*}$ significant at $5 \%$ probability

Study by Oliveira et al. (2008), where they evaluated predation by P. nigrispinus in third-instar larvae of $A$. argillacea in cotton plants under field conditions, under density of one or three caterpillars per plant, reported predation rates of 1.19 and 1.23 caterpillar/day for fifth-instar nymphs and adult females, respectively when exploring 20-day-old plants and daily availability of three caterpillars per plant. Predation rates were higher with three caterpillars per plant, regardless of leaf area, which may be due to the higher amount of prey available, which enabled the predator to locate the prey more easily (Oliveira et al., 2008). As found in this study, adult females preyed more caterpillars than fifth-instar nymphs, possibly because they are larger and need more energy for the reproductive phase. This fact was also observed by Oliveira et al. (2001) in a study on the functional response of this predator with $A$. argilacea, in which it evaluated the predation rate by adult females at the densities of one, two, four, eight and sixteen caterpillars/plant, in which a predation of 0.32 caterpillar was observed, as well as densities of one and two caterpillars per cotton plant in the flowering phase in the field, 
increasing this rate according to the prey density, with up to 3.10 prey caterpillars/day, at the density of 16 caterpillars per plant.

Podisus predation rates on various prey species and under field conditions ranged from 0.32 to 2.46 attacks per female/day (Saavedra et al., 1997; De Clercq et al., 2000; Oliveira et al., 2001; Vivan et al., 2002), mainly affected by the area to be exploited by the predator, prey density and size, plant type and weather conditions (Oliveira et al., 2008). Some studies have shown that controlled (laboratory) conditions give the bug $P$. nigrispinus high predation rates due to the ease of finding its prey (Vivan et al., 2002; Oliveira et al., 2008), therefore, the prey search capacity of this predator in the field is lower due to the larger prey search area in this environment (O’Neil, 1988; Grants, 2015).

The results found in this study show that $H$. armigera is a nutritionally suitable prey, having the necessary requirements to promote a good development and reproduction of $P$. nigrispinus in a satisfactory way, and can be used as food in mass breeding of this predator. Release of fifth-instar nymphs and adult females of $P$. nigrispinus can reduce the pest population in relation to the absence of predator under field conditions, being an alternative to be considered in $H$. armigera integrated management programs in soybean crops.

\section{References}

Angelini, M. R., \& Boiça Júnior, A. L. (2015). Biologia de Imaturos e Adultos de Podisus nigrispinus (Dallas) (Hemiptera: Pentatomidae) Alimentados com Lagartas de Dione juno juno (Cramer) (Lepidoptera: Nymphalidae), criadas em Diferentes Genótipos de Maracujazeiro. EntomoBrasilis, 8(3), 196-200. https://doi.org/10.12741/ebrasilis.v8i3.477

Avila, C. J., Vivan, L. M., \& Tomquelski, G. V. (2013). Ocorrência, aspectos biológicos, danos e estratégias de manejo de Helicoverpa armigera (Hübner) (Lepidoptera: Noctuidae) nos sistemas de produção agrícolas. Embrapa Agropecuária Oeste (Circular Técnica, 23, p. 12). Comunicado Técnico, Embrapa Dourados.

Botteon, V. W., Neves, J. A., \& Godoy, W. A. C. (2016). Functional Response and Matrix Population Model of Podisus nigrispinus (Dallas, 1851) (Hemiptera: Pentatomidae) fed on Chrysomya putoria (Wiedemann, 1818) (Diptera: Calliphoridae) as Alternative Prey. Neo. Entomology, 46(2), 137-143. https://doi.org/ 10.1007/s13744-016-0440-8

Bueno, A. F., Sosa-Gómez, D. R., Corrêa-Ferreira, B. S., Moscardi, F., \& Bueno, R. C. O. F. (2014). Inimigos Naturais Das Pragas Da Soja. In C. B. Hoffmann-Campo, B. S. Corrêa-Ferreira, \& F. Moscardi (Eds.), Soja: Manejo Integrado de Insetos e Outros Artrópodes-praga (pp. 505-508). EMBRAPA, Brazil.

CONAB. (2019). Acompanhamento da safra brasileira: Grãos: Safra 2018/2019: Décimo primeiro levantamento, 2019 (p. 104). Brasília, DF. Retrieved from file://C:/Users/Usuario/Downloads/BoletimZ GrosZagostoZ-ZCompletoZ2019\%20(1).pdf

Czepak, C., Albernaz, K. C., Vivan, L. M., Guimarães, H. O., \& Carvalhais, T. (2013). Primeiro registro de ocorrência de Helicoverpa armigera (Hübner) (Lepidoptera: Noctuidae) no Brasil. Pesq. Agrop. Tropical, 43(1), 110-113. https://doi.org/10.1590/S1983-40632013000100015

De Bortoli, S. A., Vacari, A. M., Laurentis, V. L., De Bortoli, C. P., Santos, R. F., \& Otuka, A. K. (2016). Selection of prey to improve biological parameters of the predator Podisus nigrispinus (Dallas, 1851) (Hemiptera: Pentatomidae) in laboratory conditions. Braz. J. Biology, 76(2), 307-314. https://doi.org/ 10.1590/1519-6984.12914

De Clercq, P. (2000). Predaceous stinkbugs (Pentatomidae: Asopinae). In C. W. Schaefer \& A. R. Panizzi (Eds.), Heteroptera of economic importance (pp. 737-789). Boca Raton: CRC. https://doi.org/10.1201/978142004 1859.ch32

De Clercq, P., Keppens, G., Anthonis, G., \& Degheele, D. (1988). Laboratory rearing of the predatory stinkbug Podisus sagitta (Fab.) (Heteroptera: Pentatomidae) (Vol. 53, pp. 1213-1217). Mededelingen Faculteit Landbouwwetenschappen, Universiteit Gent.

Denez, M. D., Bueno, A. F., Pasini, A., Bortolotto, O. C., \& Stecca, C. S. (2014). Biological parameters of Podisus nigrispinus (Hemiptera: Pentatomidae) fed with different soybean insect pests. Ann. Entomol. Society America, 107(5), 967-974. https://doi.org/10.1603/AN14054

Dias, P. M., Loureiro, E. S., Pessoa, L. G. A., Oliveira-Neto, F. M., Tosta, R. A., \& Teodoro, P. E. (2019). Interactions between Fungal-Infected Helicoverpa armigera and the Predator Chrysoperla externa. Insects, 10(309). https://doi.org/10.3390/insects 10100309 
Espindula, M. C., Zanuncio, J. C., Andrade, G. S., Pastori, P. L., \& Oliveira, H. N. (2010). Desenvolvimento e reprodução de Podisus nigrispinus (Heteroptera: Pentatomidae) alimentado com lagartas de Heliothis virescens (Lepidoptera: Noctuidae). Idesia, 28(3), 17-24. https://doi.org/10.4067/S0718-34292010000 300003

Fathipour, Y., \& Sedaratian, A. (2013). Integrated Management of Helicoverpa armigera in Soybean Cropping Systems. In H. El-Shemy (Ed.), Soybean-Pest Resistance (pp. 231-280). Cairo: InTech. https://doi.org/ $10.5772 / 54522$

Fehr, W. R., \& Caviness, C. E. (1977). Stages of soybean development (Special Report 80, p. 11). Ames: Iowa State University of Science and Technology.

Grants, G. E. (2015). Biologia e comportamento alimentar de Podisus nigrispinus em diferentes agroecossistemas. Rev. cien. de Agronomia, 15(28), 1-10.

Greene, G. L., Leppla, N. C., \& Dickerson, W. A. (1976). Velvet bean caterpillar: a rearing procedure and artificial medium. J. Econ. Entomology, 69(4), 487-488. https://doi.org/10.1093/jee/69.4.487

Grigolli, J. F. J., Ávila, C. J., Oliveira, H. N., Tomquelski, G. V., \& Santos, V. (2016). Mapping the occurrence and density of Helicoverpa armigera (Hbner) (Lepidoptera: Noctuidae) in Mato Grosso do Sul State, Brazil. J. Entomol. Nematology, 8, 28-33. https://doi.org/10.5897/JEN2016.0160

Guo, Y. Y. (1997). Progress in the researches on migration regularity of Helicoverpa armigera and relationships between the pest and its host plants. Acta Entomol. Sinica, 40(1), 1-6.

Juscelino-Filho, P., Zanuncio, J. C., Fragoso, D. B., Serrão, J. E., \& Lacerda, M. C. (2003). Biology of Brontocoris tabidus (Heteroptera: Pentatomidae) fed with Musca domestica (Diptera: Muscidae) larvae. Braz. J. Biology, 63, 463-468. https://doi.org/10.1590/S1519-69842003000300012

Lacerda, M. C., Ferreira, A. M. R. M., Zanuncio, T. V., Zanuncio, J. C., Bernardio, A. S., \& Espindula, M. C. (2004). Development and reproduction of Podisus distinctus (Heteroptera: Pentatomidae) fed on larva of Bombyx mori (Lepidoptera: Bombycidae). Braz. J. Biology, 64, 237-242. https://doi.org/10.1590/S151969842004000200008

Lemos, W. P., Ramalho, F. S., Serrão, J. E., \& Zanuncio, J. C. (2005). Morphology of female reproductive tract of the predator Podisus nigrispinus (Dallas) (Heteroptera: Pentatomidae) fed on different diets. Braz. Arch. Bio. Technology, 48, 129-138. https://doi.org/10.1590/S1516-89132005000100017

Mahdian, K., Kerckhove, J., Tirry, L., \& De Clercq, P. (2006). Effects of diet on development and reproduction of the predatory pentatomids Picromerus bidens and Podisus maculiventris. BioControl, 51, $725-73$. https://doi.org/10.1007/s10526-005-5253-3

Matos Neto, F. C., Zanuncio, J. C., Picanço, M. C., \& Cruz, I. (2002). Reproductive characteristics of the predator Podisus nigrispinus fed with an insect resistant soybean variety. Pesq. Agrop. Brasileira, 37, 917-924. https://doi.org/10.1590/S0100-204X2002000700004

Moura, L. A., \& Grazia, J. (2011). Record of Podisus nigrispinus (Dallas) (Hemiptera: Pentatomidae) preying on Metrogaleruca obscura Degeer (Coleoptera: Chrysomelidae). Neo. Entomology, 40, 619-621.

O’Neil, R. J. (1988). Predation by Podisus maculiventris (Say) on Mexican bean beetle, Epilachna varivestis Mulsant, in Indiana soybeans. Canadian Entomologist, 120, 161-166. https://doi.org/10.4039/Ent120161-2

O’Neil, R. J., \& Wiedenmaann, R. N. (1990). Body weight of Podisus Maculiventris (Say) under various feeding regimens. Canadian Entomol., 122, 285-293. https://doi.org/10.4039/Ent122285-3

Oliveira, H. N., \& Ávila, C. J. (2010). Controle biológico de pragas no Centro-Oeste brasileiro. G. Bio: Rev. Cont. Biológico, 11-13.

Oliveira, H. N., Espindula, M. C., Duarte, M. M., Pereira, F. F., \& Zanuncio, J. C. (2011). Development and Reproduction of Podisus nigrispinus (Hemiptera: Pentatomidae) Fed with Thyrinteina arnobia (Lepidoptera: Geometridae) Reared on Guava Leaves. Braz. Arch. Biol. Technology, 54(3), 429-434. https://doi.org/ 10.1590/S1516-89132011000300001

Oliveira, H. N., Espindula, M. C., Pratissoli, D., \& Pedruzzi, E. P. (2004a). Ganho de peso e comportamento de oviposição de Podisus nigrispinus utilizando lagartas de Spodoptera frugiperda e larvas de Tenebrio molitor como presas. Ciência Rural, 34(6), 1945-1948. https://doi.org/10.1590/S0103-84782004000600043 
Oliveira, H. N., Pratissoli, D., Pedruzzi, E. P., \& Espindula, M. C. (2004b). Desenvolvimento do predador Podisus nigrispinus alimentado com Spodoptera frugiperda e Tenebrio molitor. Pesq. Agrop. Brasileira, 39(10), 947-951. https://doi.org/10.1590/S0100-204X2004001000001

Oliveira, H. N., Simonato, J., Glaeser, D. F., \& Pereira, F. F. (2016). Parasitism of Helicoverpa armigera pupae (Lepidoptera: Noctuidae) by Tetrastichus howardi and Trichospilus diatraeae (Hymenoptera: Eulophidae). Semina Ciên. Agrárias, 37(1), 111-115. https://doi.org/10.5433/1679-0359.2016v37n1p111

Oliveira, H. N., Zanuncio, J. C., Sossai, M. F., \& Pratissoli, D. (1999). Body weight increment of Podisus nigrispinus (Stal) (Heteroptera: Pentatomidae), fed on Tenebrio molitor L. (Coleoptera: Tenebrionidae) or Musca domestica L. (Diptera: Muscidae). Brenesia, 51, 77-83.

Oliveira, J. E. M., De Bortoli, S. A., Miranda, J. E., Torres, J. B., \& Zanuncio, J. C. (2008). Predação por Podisus nigrispinus (Heteroptera: pentatomidae) sob efeito da densidade de Alabama argillacea (Lepidoptera: noctuidae) e idades do algodoeiro. Cientifica, 36(1), 1-9. https://doi.org/10.15361/1984-5529.2017 v45n $1 \mathrm{p} 1-8$

Oliveira, J. E. M., Torres, J. B., Carrano-Moreira, A. F., \& Barros, R. (2002). Efeito das plantas de tomateiro, como complemento alimentar, no desenvolvimento e na reprodução do predador Podisus nigrispinus (Dallas) (Heteroptera: Pentatomidae). Neo. Entomology, 31, 101-108. https://doi.org/10.1590/S1519-566X2 002000100014

Oliveira, J. E. M., Torres, J. B., Carrano-Moreira, A. F., \& Zanuncio, J. C. (2001). Efeito da densidade de presas e do acasalamento na taxa de predação de fêmeas de Podisus nigrispinus (Dallas) (Heteroptera: Pentatomidae) em condições de laboratório e campo. Neo. Entomology, 30(4), 647-654. https://doi.org/ 10.1590/S1519-566X2001000400020

Parra, J. R. P. (2001). Técnicas de criação de insetos para programa de Controle Biológico (p. 134). Piracicaba: ESALQ.

Peluzio, R. J. E., Castro, B. M. C., Brügger, B. P., Plata-Rueda, A., Fernandes, F. L., Santos, R. H. S., ... Zanuncio, J. C. (2018). Does diet of prey affect life table parameters of the predator Podisus nigrispinus (Hemiptera: Pentatomidae)? Flo. Entomol., 101(1), 40-43. https://doi.org/10.1653/024.101.0108

Saavedra, J. L. D., Zanuncio, J. C., Della Lucia, T. M. C., \& Reis, F. P. (1992). Efeito da dieta artificial na fecundidade e fertilidade do predador Podisus connexivus Bergroth, 1891 (Hemiptera: Pentatomidae). Anais da Soc. Entomol., 21, 69-76.

Saavedra, J. L. D., Zanuncio, J. C., Sediyama, C. S., \& Zanuncio, T. V. (1995). Fecundidad y fertility del predator Podisus nigrispinus (Dallas) (Heteroptera: Pentatomidae) en cuatro dietas artificiales. Turrialba, 45, 70-75.

Saavedra, J. L. D., Zanuncio, J. C., Zanuncio, T. V., \& Guedes, R. N. (1997). Prey captured ability of Podisus nigrispinus (Dallas) (Het., Pentatomidae) reared for successive generations on a meridic diet. J. Appl. Entomology, 121(2), 327-330. https://doi.org/10.1111/j.1439-0418.1997.tb01414.x

Santana, A. G., Avila, C. J., Oliveira, H. N., Bellon, P. P., \& Schlick-Souza, E. C. (2017). Direct and Indirect Effect of Bt Cotton and No Bt Cotton on the Development and Reproduction of the Predator Podisus nigrispinus (Dallas, 1851) (Hemiptera: Pentatomidae). Am. J. Plant Sci., 8, 1438-1448. https://doi.org/ 10.4236/ajps.2017.86098

Sibly, R. M., \& Calow, P. (1986). Physiological ecology of animals: an evolutionary approach. Blackwell Scientific, Oxford.

Specht, A., Sosa-Gómez, D. R., Paula-Moraes, S. V., \& Yano, S. A. C. (2013). Identificação morfológica e molecular de Helicoverpa armigera (Lepidoptera: Noctuidae) e ampliação de seu registro de ocorrência no Brasil. Pesq. Agrop. Brasileira, 48(6), 689-692. https://doi.org/10.1590/S0100-204X2013000600015

Stamp, N. E., Erskine, T., \& Paradise, C. J. (1991). Effects of rutin-fed caterpillars on an invertebrate predator. Oecologia, 88, 289-295. https://doi.org/10.1007/BF00320824

Thompson, S. N. (1999). Nutrition and culture of entomophagous insects. Ann. Rev. Entomology, 44, 561-92. https://doi.org/10.1146/annurev.ento.44.1.561

Torres, J. B., Zanuncio, J. C., \& Moura, M. A. (2006). The predatory stinkbug Podisus nigrispinus: biology, ecology and augmentative releases for lepidopteran larval control in Eucalyptus Forest in Brazil. CAB 
REVIEWS: Perspectives in Agriculture, Veterinary Science, Nutrition and Natural Resources, 1, 1-18. https://doi.org/10.1079/PAVSNNR20061015

Vacari, A. M., Otuka, A. K., \& Debortoli, S. A. (2007). Desenvolvimento de Podisus nigrispinus (Dallas, 1851) (Hemiptera: Pentatomidae) alimentado com lagartas de Diatraea saccharalis (Fabricius, 1794) (Lepidoptera: Crambidae). Arq. Inst. Biológico, 74, 259-265.

Vivan, L. M., Torres, J. B., Veiga, A. F. S. L., \& Zanuncio, J. C. (2002). Comportamento de predação e conversão alimentar de Podisus nigrispinus sobre a traça-do-tomateiro. Pesq. Agrop. Brasileira, 37(5), 581-587. https://doi.org/10.1590/S0100-204X2002000500002

Zamperline, B., Zanuncio, J. C., Leite, J. E. M., \& Bragança, M. A. L. (1992). Influência da alimentação de Tenebrio molitor L. 1758 (Coleoptera: Tenebrionidae) no desenvolvimento ninfal de Podisus connexivus Bergroth, 1891 (Hemiptera: Pentatomidae). Rev. Árvore, 16, 224-230.

Zanuncio, J. C., Alves, J. B., Sartório, R. C., \& Leite, J. E. M. (1992). Métodos para criação de hemípteros predadores de lagartas. Anais da Soc. Entomol., 21, 245-251.

Zanuncio, J. C., Molina-Rugama, A. J., Santos, G. P., \& Ramalho, F. S. (2002). Effect of body weight on fecundity and longevity of the stinkbug predator Podisus rostralis. Pesq. Agrop. Brasileira, 37, 1225-1230. https://doi.org/10.1590/S0100-204X2002000900004

Zanuncio, J. C., Molina-Rugama, A. J., Serrão, J. E., \& Pratissoli, D. (2001). Nymphal development and reproduction of Podisus nigrispinus (Heteroptera: Pentatomidae) fed with combinations of Tenebrio molitor (Coleoptera: Tenebrionidae) pupae and Musca domestica (Diptera: Muscidae) larvae. Biocontrol Sci. Technology, 11, 331-337. https://doi.org/10.1080/09583150120055736

\section{Copyrights}

Copyright for this article is retained by the author(s), with first publication rights granted to the journal.

This is an open-access article distributed under the terms and conditions of the Creative Commons Attribution license (http://creativecommons.org/licenses/by/4.0/). 